\title{
Medium of instruction (L1 versus L2): which is in automobile engineering?
}

\author{
Victor Dagala Medugu' ${ }^{1}$ Amirmudin Bin Udin ${ }^{2}$, Mohammad Zameri Bin Saman ${ }^{3}$ \\ ${ }^{1}$ Department of Engineering Education, Universiti Teknologi Malaysia, \\ Johor Bahru, Malaysia \\ 2Department of Technical and Engineering Education, Universiti Teknologi Malaysia, \\ Johor Bahru, Malaysia \\ ${ }^{3}$ Department of Mechanical Engineering, Universiti Teknologi Malaysia, \\ Johor Bahru, Malaysia
}

\begin{abstract}
The main purpose of the study was to establish the effects of National language (L1) as supplement to English Language (L2) in teaching and learning Motor Vehicle Mechanics (MVM) Trade as a pre- requisite course for Automobile engineering training in Technical Colleges. This was because of the massive failures of students in the said subject compared to other related engineering courses. Four specific objectives were stated to guide the study. Four corresponding research questions and two hypotheses respectively were stated based on the objectives and were tested at 0.05 level of significance. The design of the study was Quasi experimental (None equivalent) design covering all Technical Colleges in the State that offers Motor Vehicle Mechanics (MVM) Trade. There was no sampling technique used. Twenty multiple choice objective questions were administered by the researcher and the research assistant after face and content validation. Test- Retest method was used to determine the reliability of the items. Data collected were analysed using mean, standard Deviation and t-test. The results showed that the students taught (MVM) Trade using L1 as supplement performed significantly better and had positive attitudes towards MVM trade than those taught using L2.
\end{abstract}

Keywords: L1; L2; Performance; Attitude; Engineering

\section{INTRODUCTION}

Medium of instruction (L1) in this paper is the language of communication between the students and the teacher. This is the language a child is used to and can communicate with fluently from his/her childhood to adulthood stage. Motor vehicle mechanics (MVM) trade course is one of the core subjects in Technical College curriculum in Nigeria leading to the focus of Automobile Engineering. Evidence, however abounds that the students are not performing well in the subject and other science subjects for example in, physics and mathematics in their final year and pre-degree Examinations respectively (Nabteb, 2003); (Hillock et al., 2013); (Bamforth et al., 2005); (Adamuti-Trache et al., 2013). It has been noted that there was persistent failure rates of the college students in Technical and science subjects, for example; technical drawing, mathematics, chemistry and Physics over the years (Perkin, 2011); (Beanland, 2010). This was because when students find learning of concepts difficult in a subject; they end up hating the subject. 
The practice of introducing English language to the children and weaning them from L1 too early in schools alienates them from the Languages and the indigenous culture. Such alienation accordingly, leads to confusion of thought, language and adoption of nondiscriminatory attitude towards L2 and cultural influences (Miller and Bradbury, 1999). This restriction of the role of the L1 as medium of instruction to the lower levels in education accordingly has been described as being rather unfortunate and basically a perpetuation of the colonial spirit by the ruling elite.

However, research findings reported by the Hong Kong Department of Education revealed that students in L2 English-medium-instruction (EMI) were more passive in classes while those in the L1 Chinese-medium - instruction (CMI) were more active and creative in class discussions. It is also reported that students in the Chinese-medium classes performed better than those in English-medium classes in both Chinese and English on the Hong Kong Certificate of Examination (Lau and Yuen, 2011).

In The Ife Six year Education Project, the only ever been the boldest experiment in the use of L1 (Yoruba) as a medium of instruction in Nigeria, the operators employed new methods of coining, borrowing, and translation of words in order to make the Llof instruction in the experimental group while the control group switched from L1 to L2 for classroom activities. A comparison of the achievement scores indicated a consistent statistically significant superiority of the experimental group over the control group (Fafunwa et al., 2004)

A similar study conducted in Turkey indicated that students that were taught "Energy" in L2 had more misconceptions, than those in the L1 (Turkish-medium) group. Thus, the L1 of a learner (Turkish medium) seems to be more facilitative in comprehension and application of science concepts than a non-indigenous L2. It should therefore, be noted that instruction in one's national medium encourages a child to acquire desirable skills and attitudes (Kocakulah et al., 2005).

In research findings, the personalization outcome states that from beginning to the end of addressing a student in a formulating multimedia instruction in a special way, the student's achievement can be improved. This outcome can be explained with higher social charisma, with stronger self-reference or with more awareness of personal communication. Based on these explanations, by means of a local dialect instead of foreign language it can furthermore advances the student performance. As great number of Austrian students viewed a historical evident of computer network, the students were assigned randomly to single cell of formal or personalized national German or Austrian dialect between-students factorial design. The results confirmed the personalisation as a greater effect of retention and high performance. So also, the result showed a greater significant finding for both interaction and factor speech on the learners' interest (Rey and Steib, 2013).

In another development, an intervention report study of improving students literacy in South African schools of using the L1 of the country for instruction, it was confirmed that; using the L1 and the L2 rather than their dialect enhances students performance with additional high value attached to the media, but in a favourable learning environment. So, also, accordingly, it affects students that come from different languages other than the two media of instruction in test (Sailors et al., 2010).

Apart from the language of instruction, attitude to medium of instruction has been identified as another factor that affects students' achievement in science. While attitude affects achievement, achievement in return affects attitude, which emphasised that attitude could be positive, negative or ambivalent. Positive attitude could most likely result in high achievement; ambivalent attitude could be associated with medium achievement, while negative attitude could most likely lead to low achievement (Mirza et al., 2013). 
One of the impediments to the effective teaching and learning accordingly has been as the result of neglect of L1 for instruction. As reported that technology and science education students are believed to be underachieving academically as a result of the language of instruction. Accordingly, Language as a medium of communication determines largely students' achievement. It is the vehicle of thinking that helps a child to understand whatever knowledge is being imparted unto him/her; hence language and thought like body and soul are intricately interwoven (Laufer, 2009). It therefore becomes imperative for exploring by means of empirical evidence the effect of L1 in delivery of teaching and learning of MVM for determining students' performance

\section{METHODOLOGY}

This paper was examined based on quasi-experimental (non-equivalent control group research).The research often is dependent upon the natural setting in which the research was investigated.

The research article explored the opportunity of collected data in the situations where nature has performed or is performing her own experiment. This design controls all the threats to both internal and external validity such as history, maturation, testing, experimental mortality, statistical regression, selection bias, instrumentation and interaction. These are factors jeopardising internal and external validity of experimental findings (Sambo, 2005).

This examination design is diagrammatically presented as follow:

$$
\begin{array}{lll}
\text { Ge } & X & \text { Y1 } \\
\text { GC } & & \text { Y2 }
\end{array}
$$

where; Ge was the experimental group, Gc was the control group. Y indicates that subjects were not assigned randomly but intact classes were used for the treatment, $\mathrm{X}$ indicate treatment group. However, in this article, the design is presented as follows:

$\begin{array}{llll}\text { Ge1 } & \text { Y } & \text { X1 } & \text { Y1 } \\ \text { Ge2 } & \text { Y } & \text { X2 } & \text { Y2 } \\ \text { Gc } & Y & & \text { Y1 }\end{array}$

In this paper, G1 and G2 were experimental groups and Gc was the control group. Only the experimental (L1) groups were given treatment. The control group was taught MVM in L2 medium. Four topics were selected for the treatment and were broken down into smaller teachable units using the comprehensive lesson plans and lesson notes for the instruction. The treatment was done during the normal lesson periods two times a week for four weeks. The treatment was done simultaneously to each group. The groups were taught different topic at a time, but chosen from the topics selected for this article.

\section{RESULTS}

The presentation of the result followed the research question to the hypothesis to justify the experimental finding of the outcome. In answering the research question, mean and standard deviations were employed as statistical tools and t-test was used to test the hypothesis at 0.05 level of significance. 


\section{1. Research Question}

What are the students mean achievement in MVM trade when taught using L1 as supplement and L2 as the medium of instruction?

Table 1. The Means and Standard Deviations of the Students' Scores in MVM Trade after treatment (post-test scores) using L1 and L2.

\begin{tabular}{lccr}
\hline Groups & $\mathrm{N}$ & $\bar{X}$ & $\mathrm{SD}$ \\
\hline Experimental (1) & 25 & 50.08 & 9.70 \\
Experimental (2) & 25 & 47.20 & 14.49 \\
Control & 26 & 38.38 & 8.49 \\
\hline
\end{tabular}

From Table 1, the experimental group (1) had the highest mean score of 50.08 with the corresponding standard deviation of 9.70. This was followed closely by the experimental group (2) with the mean score of 47.20 with its corresponding standard deviation of 14.49 in MVM achievement test.

The control group scored the lowest mean score of 38.38 with the corresponding standard deviation of 8.49 in the same test. L2 proved to be faulty or inappropriate because the control group scored the lowest mean score in the MVM trade achievement test.

\section{2. Null Hypothesis (HO)}

There is no significant difference between the mean achievement of the students when taught MVM Trade using L1 as supplement and L2 for the instructions.

Table 2. T-test Result of the Mean Achievement Scores of the Students in MVM Trade when taught using L1 as Supplement and L2 for the Instruction.

\begin{tabular}{lcccccccr}
\hline Group & $\mathrm{N}$ & $\bar{X}$ & $\mathrm{SD}$ & $\mathrm{df}$ & Standard & t-cal. & t-Critical & Decision \\
\hline Experimental & 50 & 48.64 & 11.05 & 74 & 0.46 & 3.27 & 1.66 & \\
$\begin{array}{l}\text { Control } \\
\text { HO }\end{array}$ & 26 & 40.54 & 9.82 & & & & & Reject \\
\hline
\end{tabular}

Table 2 shows t-test analysis of the mean achievement scores of the two groups when taught MVM trade using L1as supplement and L2 for the instruction at 0.05 level of significance. T-calculated was found to be 3.27 and the t- critical was 1.66 . Since the tcalculated is greater than t-critical, the Ho was rejected

\section{3. Findings}

L1 was confirmed to be the most facilitative medium of communication in teaching and learning at technical college level. Using L1 for instruction created positive academic performance of students towards MVM trade. Significant difference exists between the mean 
achievement scores of the students towards MVM trade when taught using L1 as the medium of instruction

\section{CONCLUSION}

Based on the outcomes of the paper, the following conclusions were drawn:

Poor performance in the NABTEB examination and apparent lack of communicative language among MVM trade students at the technical college levels in Adamawa state confirmed the bases for this study. Among the two teaching media investigated for teaching and learning of MVM trade, L1 yielded the best result. This is because students taught using L1 scored the highest post-test mean scores and standard deviations.

Finally, as an approach to effective teaching and learning, it requires that teachers should be encouraged to use the language L1 for communication during teaching and learning of MVM. Therefore, there is no doubt based on the result of this paper, if L1 is integrated into MVM teaching and learning it will yield higher academic performance results in MVM in Technical colleges.

\section{Recommendations}

Based on the findings and conclusions of the study, the researcher recommended that:

I. Technical teachers should be encouraged to use L1 in teaching and learning of MVM trade for making learning real and concrete.

II. Workshops and seminars be organised for technical teachers and in particular for the MVM teachers on the use of L1 to communicate to the learners in teaching and learning of technical trade subjects

III. Principals, supervisors and directors of technical education should encourage the use of L1 mandatory for teaching and learning of technical/vocational trades at technical college levels.

\section{References}

[1] Adamuti-Trache M., Bluman G., Tiedje T. (2013). Student Success in First-Year University Physics and Mathematics Courses: Does the High-School Attended Make a Difference? International Journal of Science Education, 35(17); 2905-2927.

[2] Bamforth S., Crawford A., Croft A., Robinson C. (2005). A Pre-Sessional Course: Retaining Engineering Students through Mathematical and Transferable Skills Support. International Journal of Electrical Engineering Education, 42(5); 79-87.

[3] Beanland D. G. (2010). Challenges and Opportunities Facing the Education of Engineers - Address to Victoria Division of Engineers Australia Seg Meeting, Melbourne.

[4] Fafunwa A. B., Macauley J. I., Sokoya I. A. (2004). Education in Mother Tongue, Ile-Ife Primary Education Research. Internet Journal of Education. Ibadan, Nigeria: University Press Limited. 
[5] Hillock P. W., Jennings M., Robert A., Scharaschkin V. (2013). A Mathematics Support Programme for First-Year Engineering Students. International Journal of Mathematical Education in Science and Technology, 44(7); 1030-1044.

[6] Kocakulah S., Ustunluoglu E., Kocakulah A. (2005). The Effect of Teaching in Native and Foreign Language on Students' Conceptual Understanding in Science Courses AsiaPacific Forum on Science Learning and Teaching, 6(2).

[7] Laufer B. (2009). Second Language Vocabulary Acquisition from Language Input and from Form-Focused Activities. ournal of Language Teaching, 42(2); 341-354.

[8] Miller R., Bradbury J. (1999). Academic Performance of English First and Second Language Students:Selection Criteria. South African Journal of Science, 95(1); 30-40.

[9] Mirza N. S., Sadia S., Mirza A. A. (2013). The Role of "Radical Change" in L1 and Its Implication on Learning. Journal of Language Teaching and Research. Journal of Language teaching and Research, 4(1); 36-44.

[10] Nabteb (2003). Guideline or Admission into Federal/ State Technical Colleges in Nigeria. Binin City, Nigeria.

[11] Perkin G., Bamforth S. (2011). A Variety of Approaches to the Provision of Mathematics Help for First-Year Engineering Undergraduates, International Journal of Electrical Engineering Education, 48(1); 79-91.

[12] Rey G. D., Steib N. (2013). The Personalization Effect in Multimedia Learning: The Influence of Dialect. Computer in human behaviour-journal, 29(5); 2022-2028.

[13] Sailors M., Hoffman J. V., Pearson P. D., Beretvas S. N., Matthee B. (2010). The Effects of First- and Second-Language Instruction in Rural South African Schools. Bilingual research journal, 33(1); 21-41.

[14] Sambo A. A. (2005). Reseach Methods Education. Lagos, Ibadan, Benin City, JattuUzairue: Sterling Horden (Nig.) Ltd.

[15] Hussein Meihami, Zeinab Varmaghani, International Letters of Social and Humanistic Sciences 9 (2013) 49-58.

[16] Hussein Meihami, Bahram Meihami, International Letters of Social and Humanistic Sciences 2 (2014) 10-19.

[17] Hussein Meihami, Bahram Meihami, International Letters of Social and Humanistic Sciences 5 (2014) 35-43. 